\title{
Weaning and Field Survival Responses of Propagules to Propagating Structures and Seedling Types in Sheanut Production in Tropical Africa
}

\author{
Julius Yeboah1, Ben Kwaku Branoh Banful2, Frank Manu Amoah1, \\ Bonaventure Kissinger Maalekuu2, Peter Yaw Boateng2 \\ ${ }^{1}$ Cocoa Research Institute of Ghana (CRIG), Tafo-Akim, Ghana \\ ${ }^{2}$ Department of Horticulture, Kwame Nkrumah University of Science and Technology, Kumasi, Ghana \\ Email: bproofa@gmail.com
}

Received 11 May 2014; revised 9 June 2014; accepted 27 June 2014

Copyright (C) 2014 by authors and Scientific Research Publishing Inc. This work is licensed under the Creative Commons Attribution International License (CC BY). http://creativecommons.org/licenses/by/4.0/

(c) (i) Dpen Access

\section{Abstract}

The Shea is an economic tree found in West and Central Africa with huge industrial uses in the confectionery, pharmaceutical and cosmetic sectors worldwide. Its rapid multiplication has been hampered by its slow growth and long gestation period. Successes in cutting propagation have been achieved (between 60\% - 80\%), however weaning of the rooted cuttings for establishment has been a major challenge. Two factorial experiments were carried out in a study in 2012. The objective of this study was to determine the effects of propagating structures and seedling types on the weaning and subsequent field establishment of propagules of Shea tree for plantation establishment. A randomized complete block design with three replications was used. Survival of the rooted cuttings in the mist propagator was very high $(93.3 \%)$ and comparable to that of the seedlings $(100 \%)$. The rooted cuttings in mist propagator produced the highest number of leaves, 11 times greater than the least number of leaves produced by seedlings in the lath house. Comparing the seedling types, the rooted cuttings produced significantly greater number of leaves, 4.8 times than the normal seedlings. Rooted cuttings in the mist propagator produced the biggest stem girth significantly greater than the seedlings kept in all the structures. The rooted cuttings in the mist propagator produced 4.4 times bigger stem girths than the seedlings in the lath house which had the smallest stem girth. The rooted cuttings in the mist propagator produced the tallest plants, 1.4 times and 1.9 times significantly taller than the seedlings in the propagating pit and lath house, respectively, which produced the shortest plants. There was a significant relationship between field survival of propagules and the month of establishment expressed as $Y$ (percent survival) $=-2844+0.070 \times($ month $) ; P<0.001 ; R^{2}=0.68 ; n=90$. Rooted cuttings transplanted in a hole depth of $52.0 \mathrm{~cm}$ produced the biggest stem girth, 5.6 times bigger than the stem girth of the 
seedlings transplanted into any of the three hole depths. Rooted cuttings transplanted into a hole depth of $52.0 \mathrm{~cm}$ produced the highest number of leaves, three times more than the seedlings in $26 \mathrm{~cm}$ hole depth, which produced the least number of leaves. The study concluded that the mist propagator was the most suitable propagating structure for weaning rooted cuttings of sheanut tree since it resulted in higher survival of the rooted cuttings as well as promoted the growth of the rooted cuttings. For field establishment, rooted cuttings transplanted into hole depth of $52 \mathrm{~cm}$ resulted in higher survival rates and performed better in terms of growth than the seedlings. Furthermore, the month of establishment was very critical for the rate of survival of the transplanted propagules of Shea tree.

\section{Keywords}

\section{Vitellaria paradoxa, Propagating Structures, Seedling Types, Hole Depths}

\section{Introduction}

Shea (Vitellaria paradoxa Gaertn.) trees grow naturally throughout the Sudanian region from Senegal to the foothills of the Ethiopian highlands [1]. It is found in nineteen countries across East, Central and West Africa [2]. It is an important tree species serving as a source of income for many inhabitants of the semi-arid region of West Africa. The edible fruits of the tree contain large quantities of vitamin C, proteins and minerals [3]. These fruits are eaten, especially during the lean season, and therefore serve as a food stopgap throughout the Guinea and Interior Savanna regions of West Africa [4]. Economically, the nut of the fruit contains Shea butter which has characteristics similar to that of cocoa butter ([5] [6]) and as such easily substitutes for the highly demanded cocoa butter in the confectionery, pharmaceutical and cosmetic industries worldwide [7].

In spite of these tremendous economic benefits, the Shea tree has remained largely undomesticated due to its natural long gestation period of 12 - 20 years. This phenomenon makes the sheanut tree very unattractive for commercial cultivation. Over the years, reduction in the gestation period of the tree has been achieved using vegetative propagation techniques such as cuttings ([8]-[12]), grafting ([13]) and air-layering ([14] [15]). The major challenge after propagation is the weaning and subsequent field establishment of the rooted propagules. Farmer survey studies indicate that weaning of the rooted propagules is mostly carried out by farmers in the dry season resulting in very low responses. Yeboah et al., [8] reported that weaning response could be as low as $20 \%$ when carried out in the dry season. Further, the subsequent field establishment survival rates are even much lower [9]. Tremendous success rates have however been recorded in other fruit tree species such as apple and pear [16]. In their study, they used a combination of propagating structures and different rooted seedlings which produced the resultant high successes. The objective of this study therefore was to determine the effects of these propagating structures and seedling types on the weaning and subsequent field establishment of propagules of Shea tree for plantation establishment.

\section{Materials and Methods}

\subsection{Characteristics of the Experimental Site}

The experiments was carried out from May to December, 2012 at the Cocoa Research Institute of Ghana substation at Bole in the Northern region of Ghana, $9^{\circ} 01^{\prime} \mathrm{N}, 2^{\circ} 29^{\prime} \mathrm{W}$. The substation is located in the Interior Savanna agro-ecological zone. The experimental period was characterized by high rainfall (mean rainfall of 102.6), high relative humidity (mean humidity of 78.2 and 69.1 ) and moderate temperature $\left(29.8^{\circ} \mathrm{C} ; 23.6^{\circ} \mathrm{C}\right)$.

\subsection{Experimental Procedure}

\section{Experiment 1}

The objective of this experiment was to determine the effect of propagating structures and seedling types on the weaning of rooted propagules. The design was $2 \times 3$ factorial arrangement in a randomized complete block design with three replications. The first factor was propagating structure at three levels viz; mist propagator; 
propagating pit $(3.0 \mathrm{~m} \times 0.9 \mathrm{~m} \times 0.2 \mathrm{~m})$ and Lath house. The second factor was seedling type at two levels viz; normal seedlings; rooted cuttings. The mist propagator was a structure of wood covered with transparent polythene sheet. Spraying nozzles were fixed on top of the structure to spray water in the form of mist. The mist propagator was kept under a shade net to provide $50 \%$ shade.

The propagating pit was a rectangular structure with dimensions $3.0 \mathrm{~m} \times 0.9 \mathrm{~m} \times 0.2 \mathrm{~m}$. A flexible metal dome was placed on top of the structure and covered with a transparent polythene sheet. The pit structure was also kept under a shade net to provide $50 \%$ shade.

The lath house was used as the control structure in the experiment.

\subsection{Production of Propagules for Experiments}

Normal seedlings: Seeds harvested from selected trees were nursed in polythene bags $30 \mathrm{~cm}$ long $\times 17 \mathrm{~cm}$ wide and filled with top soil in May.

Rooted cuttings: Cuttings were harvested from the same trees and set in pit propagators using indolebutyric acid (IBA) as root inducing hormone and rice husk as medium. Rooted cuttings were harvested 60 days after setting in pit propagators and potted into polythene bags $(30 \mathrm{~cm}$ long $\times 17 \mathrm{~cm}$ wide) filled with top soil.

Both potted seedling types were kept in the propagating structures from July to last week of September for the weaning studies. Water was provided in each structure at $06.00 \mathrm{hrs}$ and $14.00 \mathrm{hrs}$ GMT. For the mist propagator the water was provided as mist whereas for the two other structures a watering can was used to provide water for the seedlings.

Data were collected on (i) ambient climatic parameters; (ii) percentage of survived propagules; (iii) leaf production of propagules; (iv) stem girth of propagules; (v) plant height of propagules.

\section{Experiment 2}

The objective of this experiment was to determine the effect of transplanting hole depth and seedling type on the field establishment of weaned propagules. The design was $2 \times 3$ factorial arrangement in a randomized complete block design with three replications. The first factor, was hole depth at three levels viz; $26 \mathrm{~cm}$ depth; $39 \mathrm{~cm}$ depth; $52 \mathrm{~cm}$ depth.

The length and width of each hole size was maintained at $52 \mathrm{~cm} \times 52 \mathrm{~cm}$. The second factor was seedling type at two levels viz; normal seedlings; rooted cuttings.

After weaning, the seedlings were hardened for five weeks before transplanting to the field.

Data were collected on (i) climatic parameters recorded daily with a data logger; (ii) number of survived plants six months after field establishment; (iii) plant height six months after field establishment; and (iv) stem girth six months after field establishment; (v) soil moisture taken four weeks after transplanting using a moisture meter; (vi) soil temperature taken four weeks after transplanting using Earth thermometers.

For the two experiments, the seedlings and cuttings were raised in May prior to the commencement of the experiments in July to September (weaning experiment) and from November to April (establishment experiment).

\subsection{Statistical Analysis}

Data were analyzed by analysis of variance (ANOVA), using Gentstat version 9. Counts data were square root transformed. Least significant differences (LSD) were calculated and the probability of treatment means being significantly different was set at $\mathrm{P}=0.05$.

\section{Results}

\subsection{Monthly Ambient Climate Dynamics}

The climatic data during the experimental period is presented in Table 1. Low to moderate temperatures were recorded from May to September and thereafter high temperatures were experienced from October to December, 2012. A similar trend was recorded for relative humidity over the period. However, rainfall was high from May, to September and tapered from October with no rainfall recorded in December, 2012.

\section{Mean Morning and Afternoon Humidity Figures in Different Structures}

The propagating mist recorded high humidity figures for both the morning and afternoon, while the lath house recorded the lowest (Table 2). The propagating mist and pit did not significantly differ in the morning humidity. 
Table 1. Climatic data from May to December, 2012.

\begin{tabular}{|c|c|c|c|c|c|}
\hline \multirow{2}{*}{ Month } & \multicolumn{2}{|c|}{ Mean Temperature ${ }^{\circ} \mathrm{C}$} & \multicolumn{2}{|c|}{ Mean Relative Humidity } & \multirow{2}{*}{$\begin{array}{c}\text { Total Rainfall } \\
\text { mm }\end{array}$} \\
\hline & Max & Min & $9.00 \mathrm{am}$ & $3.00 \mathrm{pm}$ & \\
\hline May & 30.0 & 24.5 & 82.0 & 70.0 & 115.8 \\
\hline June & 29.8 & 23.6 & 88.0 & 78.0 & 157.2 \\
\hline July & 29.8 & 23.2 & 84.0 & 71.0 & 121.7 \\
\hline August & 28.6 & 22.1 & 87.5 & 68.4 & 113.6 \\
\hline September & 30.3 & 24.5 & 90.6 & 79.0 & 215.4 \\
\hline October & 32.0 & 22.2 & 82.2 & 59.2 & 78.7 \\
\hline November & 33.8 & 21.6 & 73.4 & 50.7 & 15.9 \\
\hline December & 34.7 & 19.2 & 44.8 & 27.2 & 0.0 \\
\hline
\end{tabular}

Table 2. Mean morning and afternoon humidity percentage in different propagating structures.

\begin{tabular}{ccc}
\hline Propagating Structures & Mean Humidity at 9.00 a.m. (\%) & Mean Humidity at 3.00 p.m. (\%) \\
\hline Mist Propagator & 87.5 & 60.2 \\
Propagating pit & 82.6 & 69.2 \\
Lath house & 61.1 & 42.4 \\
\hline
\end{tabular}

$\operatorname{LSD}(5 \%), 5.42,4.96$.

\subsection{Growth Performance of Propagules during Weaning}

\subsubsection{Effects of Propagating Structure and Seedling Type on the Percent Survival of Propagules during Weaning}

There was significant $(\mathrm{P}<0.05)$ container structure and seedling type interaction for the survival rate of propagules during the weaning period of three months (Table 3). Seedlings, as propagules, produced the highest survival rate of $100 \%$, significantly different from the survival rates of the other treatment combinations. The only exception was rooted cuttings in mist propagator which was not significantly different from the seedlings survival rate in any of the structures. Generally, the mist propagator resulted in a significantly higher rate of survival of propagules than the lath house, though similar to the survival rate from the propagating pit (Table 3).

\subsubsection{Effects of Propagating Structure and Seedling Type on Leaf Production of Propagules during Weaning}

Significant $(\mathrm{P}<0.05)$ structure and seedling type interaction was also observed for the production of leaves of the propagules during weaning (Table 4). The rooted cuttings in mist propagator produced the highest number of leaves, 11 times greater than the least number of leaves produced by seedlings in the lath house. Comparing the seedling types, the rooted cuttings produced significantly greater number of leaves, 4.8 times than the normal seedlings. In addition, both mist propagator and propagating pit resulted in the production of more leaves than the Lath house (Table 4).

\subsubsection{Effects of Propagating Structure and Seedling Type on Stem Girth of Propagules during Weaning}

There was significant $(\mathrm{P}<0.05)$ structure and seedling type interaction for stem girth of the propagules. Rooted cuttings in the mist propagator produced the biggest stem girth significantly greater than the seedlings kept in all the structures (Table 5). Similarly, stem girth of the rooted cuttings in the propagating pit was significantly bigger than the seedlings in the lath house. The rooted cuttings in the mist propagator produced 4.4 times bigger stem girths than the seedlings in the lath house which had the smallest stem girth. 
Table 3. The effects of propagating structures and seedling types on the percent survival of propagules over a 3-month weaning period.

\begin{tabular}{cccc}
\hline & \multicolumn{2}{c}{ Percent Survival (\%) } \\
\cline { 2 - 4 } Propagating Structure & \multicolumn{2}{c}{ Seedling Type } & Mean \\
\cline { 2 - 4 } & Rooted Cuttings & Seedlings & 96.7 \\
Mist Propagator & 93.3 & 100.0 & 88.4 \\
Propagating Pit & 76.7 & 100.0 & 75.0 \\
Lath House & 50.0 & 100.0 & 100.0 \\
Mean & 73.3 & & \\
\hline
\end{tabular}

LSD 5\%: Propagating structure = 19.7; Seedling type = 19.2; Propagating Structure $\times$ Seedling type = 21.3.

Table 4. The effects of propagating structures and seedling types on the leaf production of propagules over a 3-month weaning period.

\begin{tabular}{cccc}
\hline & \multicolumn{2}{c}{ Number of Leaves } \\
\cline { 2 - 4 } Propagating Structure & \multicolumn{2}{c}{ Seedling Type } & Mean \\
\cline { 2 - 4 } & Rooted Cuttings & Seedlings & 73.5 \\
Mist Propagator & 122.3 & 24.7 & 62.7 \\
Propagating Pit & 103.0 & 22.3 & 30.2 \\
Lath House & 49.7 & 10.7 & 19.2 \\
\hline
\end{tabular}

LSD 5\%: Propagating structure = 16.3; Seedling type = 13.3; Propagating Structure $\times$ Seedling type $=21.1$.

Table 5. The effects of propagating structures and seedling types on stem girth of propagules over a 3-month weaning period.

\begin{tabular}{ccc}
\hline & \multicolumn{2}{c}{ Stem Girth (mm) } \\
\cline { 2 - 3 } Propagating Structure & \multicolumn{2}{c}{ Seedling Type } \\
\cline { 2 - 3 } Mist Propagator & Rooted Cuttings & Seedlings \\
Propagating Pit & 2.6 & 1.2 \\
Lath House & 2.2 & 1.2 \\
Mean & 1.7 & 0.6 \\
1.9 \\
\hline
\end{tabular}

LSD $(5 \%)$, Structure $=1.0 ;$ Seedling type $=1.1 ;$ Structure $\times$ Seedling type $=1.3$.

\subsubsection{Effects of Propagating Structure and Seedling Type on Plant Height of Propagules during \\ Weaning}

Plant height of propagules responded to a significant $(\mathrm{P}<0.05)$ structures $\mathrm{x}$ seedling type interaction (Table 6). The rooted cuttings in the mist propagator produced the tallest plants, 1.4 times and 1.9 times significantly taller than the seedlings in the propagating pit and lath house, respectively, which produced the shortest plants.

\subsection{Field Establishment of Weaned Propagules}

\subsubsection{Relationship between Field Survival and Period of Field Establishment Propagules}

There was a significant relationship between field survival of propagules and the month of establishment. The 
month of field establishment accounted for $68 \%$ of the variation in the percent survival of the propagules. The relationship was expressed as

$\mathrm{Y}($ percent survival $)=-2844+0.070 \times($ month $) ; \mathrm{P}<0.001 ; \mathrm{R}^{2}=0.68 ; \mathrm{n}=90$.

\subsubsection{Effects of Hole Depth on Soil Temperature and Moisture}

There were significant differences in soil temperature and moisture between the hole depths. Soil temperature was lowest at $52 \mathrm{~cm}$ depth, significantly lower than those at $39 \mathrm{~cm}$ and $26 \mathrm{~cm}$ hole depths (Table 7). Conversely, soil moisture was highest at $52 \mathrm{~cm}$ depth, significantly greater than at $26 \mathrm{~cm}$ depth yet similar to moisture at 39 cm depth.

\subsubsection{Effects of Hole Depth and Seedling Type on Survival of Transplanted Weaned Propagules} There was significant hole depth $\times$ seedling type interaction for the percent survival of transplanted propagules in the dry season (Table 8). Normal seedlings planted to a depth of $52 \mathrm{~cm}$ produced the highest percentage of survived transplants significantly different from the rooted cuttings planted to a similar depth of $52 \mathrm{~cm}$. Generally at each depth, the normal seedlings produced significantly greater percentage of survived transplants than the corresponding rooted cuttings (Table 8).

Table 6. The effects of propagating structures and seedling types on plant height of propagules over a 3-month weaning period.

\begin{tabular}{|c|c|c|c|}
\hline \multirow{3}{*}{$\begin{array}{l}\text { Propagating } \\
\text { Structure }\end{array}$} & \multicolumn{3}{|c|}{ Plant Height (cm) } \\
\hline & \multicolumn{2}{|c|}{ Seedling Type } & \multirow{2}{*}{ Mean } \\
\hline & Rooted Cuttings & Seedlings & \\
\hline Mist Propagator & 5.5 & 5.0 & 5.3 \\
\hline Propagating Pit & 4.9 & 4.0 & 4.5 \\
\hline Lath House & 4.3 & 2.9 & 3.6 \\
\hline Mean & 4.9 & 4.0 & \\
\hline
\end{tabular}

LSD (5\%): Propagating Structure = 1.2; Seedling type = $1.3(\mathrm{~ns})$; Propagating Structure $\times$ Seedling type = 1.5.

Table 7. Effect of hole depth on soil temperature and soil moisture averaged over six months.

\begin{tabular}{rcc}
\hline Hole depth & Mean Soil Temperature ${ }^{\circ} \mathrm{C}$ & Mean Soil Moisture \% \\
\hline 26 cm Depth & 29.1 & 43.0 \\
39 cm Depth & 27.4 & 45.6 \\
52 cm Depth & 24.2 & 47.0 \\
\hline
\end{tabular}

LSD (5\%). 2.49, 1.62.

Table 8. Effect of hole depth and seedling type on the survival of transplanted weaned propagules of Shea tree nut in the dry season.

\begin{tabular}{|c|c|c|c|}
\hline \multirow{2}{*}{ Hole Depth (cm) } & \multicolumn{3}{|c|}{ \% Survival of Transplanted Propagules } \\
\hline & Seedling Type Rooted Cuttings & Seedlings & Mean \\
\hline 26 cm Depth & 60.0 & 80.0 & 70.0 \\
\hline 39 cm Depth & 65.0 & 85.0 & 75.0 \\
\hline $52 \mathrm{~cm}$ Depth & 75.0 & 90.0 & 82.5 \\
\hline Mean & 66.7 & 85.0 & \\
\hline
\end{tabular}

LSD 5\% Hole depth $=$ ns; Seedling type $=$ ns; Hole depth $\times$ Seedling type $=19.5$. 


\subsubsection{Effects of Hole Depth and Seedling Type on Stem Girth of Transplanted Propagules Six} Months after Field Establishment

There was significant $(\mathrm{P}<0.05)$ hole depth $\times$ seedling type interaction for stem girth of propagules established in the field such that rooted cuttings transplanted in a hole depth of $52.0 \mathrm{~cm}$ produced the biggest stem girth, 5.6 times bigger than the stem girth of the seedlings transplanted into any of the three hole depths (Table 9).

\subsubsection{Effects of Hole Depth and Seedling Type on Plant Height and Stem Girth of Transplanted Propagules Six Months After field Establishment}

There were no significant differences in plant height of the transplanted propagules after six months of field establishment. However in terms of leaf production, there was significant $(\mathrm{P}<0.05)$ hole depth $\mathrm{x}$ seedling type interaction such that rooted cuttings transplanted into a hole depth of $52.0 \mathrm{~cm}$ produced the highest number of leaves, three times more than the seedling in $26 \mathrm{~cm}$ hole depth, which produced the least number of leaves (Table 10). Furthermore, the rooted cuttings in each of the hole depths produced significantly more leaves that the seedlings in both $26 \mathrm{~cm}$ and $39 \mathrm{~cm}$ hole depths, the exception being seedlings in $52 \mathrm{~cm}$ hole depth (Table 10).

\section{Discussion}

\subsection{Growth Performance of Propagules during Weaning}

Survival of the rooted cuttings in the mist propagator was very high and comparable to that of the seedlings. The lath house on the other hand, recorded the least survival of the rooted cuttings. The micro humidity and temperature around the cuttings could be the reason for the observed differences. This is because in the mist propagator due to the frequent provision of water in the form of mist, the humidity around the cuttings was always very high coupled with a lowering of the temperature also around the cuttings. This observation is corroborated by [16] who indicated that high humidity and low temperature are suitable microclimate for the survival and development of cuttings because they ensure low evapo-transpiration and prevent moisture stress in the cuttings.

Table 9. Effect of hole depth and seedling type on the stem girth of transplanted propagules six months after field establishment.

\begin{tabular}{cccc}
\hline & \multicolumn{2}{c}{ Stem Girth (mm) } \\
\cline { 2 - 4 } Hole Depth $(\mathrm{cm})$ & \multicolumn{2}{c|}{ Seedling Type } & Mean \\
\cline { 2 - 4 } & Rooted Cuttings & Seedlings & 1.0 \\
\hline 26 cm Depth & 1.3 & 0.6 & 1.5 \\
39 cm Depth & 2.4 & 0.6 & 2.1 \\
52 cm Depth & 3.4 & 0.7 & 0.6 \\
Mean & 2.4 & & \\
\hline
\end{tabular}

LSD (5\%): Hole depth = 1.0; Seedling type $=1.1 ;$ Hole depth $\times$ Seedling type $=1.3$

Table 10. Effect of hole depth and seedling type on the number of leaves of transplanted propagules six months after field establishment.

\begin{tabular}{cccc}
\hline & \multicolumn{3}{c}{ Number of Leaves Produced } \\
\cline { 2 - 4 } Hole Depth (cm) & \multicolumn{2}{c}{ Seedling Type } & Mean \\
\cline { 2 - 4 } & Rooted Cuttings & Seedlings & 3.0 \\
\hline Hole Depth (26.0) & 4.0 & 1.9 & 3.5 \\
Hole Depth (39.0) & 4.5 & 2.4 & 4.7 \\
Hole Depth (52.0) & 5.7 & 3.7 & 2.7 \\
\hline
\end{tabular}

LSD (5\%): Hole depth = 1.2 (ns); Seedling type= 1.2; Hole depth $\times$ Seedling type $=1.5$. 
As regards the seedlings, the presence of their deep taproot systems in the polythene bags enabled them to withstand the harsh ambient weather conditions.

In the lath house, humidity was low; the least amongst the propagating structures and therefore accounted for the low survival of the rooted cuttings. During the weaning period, leaf production of the rooted cuttings in the mist propagator was about 2.5 times greater than similar rooted cuttings in the lath house and 6.5 times more than the mean number of leaves of the seedlings across the propagating structures. Very high humidity as evidenced in the mist propagator has been implicated as a possible factor enhancing leaf formation and production since it promotes the breaking of leaf buds through the provision of endogenous substances such as cytokinins to the buds which allows them to mature and break ([17]-[19]). Moreover, [16] indicated that humidity management was an effective tool in enhancing plant growth because it ensured the presence of moisture in the environment which enhanced rapid cell processes like cell division, vitamins production, protein synthesis, auxin synthesis and DNA production. Plant height and stem girth of the rooted cuttings were however similar for all the propagating structures during the weaning period of three months. In comparison to the seedlings, the rooted cuttings in the mist propagator recorded better growth in terms of leaf production, plant height and stem girth.

\subsection{Field Establishment of Weaned Propagules}

The period of field establishment coincided with good rains which facilitated the high survival rate of the transplanted propagules. It is therefore not surprising that the month of field establishment significantly accounted for $68 \%$ of the variation in the survival of the transplanted propagules. Generally, the percent survival of the transplanted seedlings was significantly higher than the rooted cuttings due mainly to the rooting system possessed by the two propagules; seedlings with a long tap root whereas the rooted cuttings had adventitious roots. Consequently, the seedlings were better able to explore and draw on the soil resources than the rooted cuttings with the shallow adventitious roots. Naturally, the Shea tree has a long tap root with very limited secondary and tertiary roots. By this root system, it draws more on soil resources from the deeper layers than from the superficial layers and this in part accounts for its slow growth in nature. In the present study, once established, the transplanted rooted cuttings performed better in terms of growth than the seedlings as observed in its recording of 5.6 times bigger stem girth and 1.7 times more leaves than the seedlings across all the hole depths. This could probably be due to the fact that the rooted cuttings had a better root system in terms of having more secondary and tertiary roots in addition to the developed tap root six months after establishment thus enhancing the ability of the rooted cuttings to explore both the superficial and deeper layers of the soil to facilitate growth. Within the rooted cuttings, transplanting into a hole of $52 \mathrm{~cm}$ depth produced significantly better growth in stem girth and leaf production than transplanting into a $26 \mathrm{~cm}$ hole. This could be explained by the fact that the $52 \mathrm{~cm}$ hole facilitated the development of a long tap root, a natural tendency of Shea tree, than the more shallow $26 \mathrm{~cm}$ hole depth which impeded root development and growth. Furthermore, at the deepest depth of $52 \mathrm{~cm}$, soil temperature was lowest whiles soil moisture was greatest. Moderate soil temperatures help the root system of the plants to function well in absorption of water and nutrients [20] whiles high soil moisture helps the roots to extract water to the shoots for the dissolution of soluble nutrients for growth ([16] [21]). The high soil moisture at the 52 $\mathrm{cm}$ hole depth might have provided a conducive environment for efficient functioning of soil microorganisms that were involved in soil biogeochemical processes including organic matter decomposition and synthesis of hormones and organic acids which aid nutrient release from soil for enhanced uptake by plants [22].

\section{Conclusion}

The study clearly demonstrated that the mist propagator was the most suitable propagating structure for weaning rooted cuttings of sheanut tree since it resulted in higher survival of the rooted cuttings as well as promoted the growth of the rooted cuttings. For field establishment, rooted cuttings transplanted into hole depth of $52 \mathrm{~cm}$ resulted in higher survival rates and performed better in terms of growth than the seedlings as observed in its recording of 5.6 times bigger stem girth and 1.7 times more leaves than the seedlings across all the hole depths. Finally the study demonstrated that the month of establishment was very critical for the rate of survival of the transplanted propagules.

\section{Acknowledgements}

The authors express sincere thanks to the technical staff at the CRIG substation, Bole for the data collection. 
This publication No. CRIG/12/2014/017/003 is published by the kind permission of the Executive Director of the Cocoa Research Institute of Ghana. .

\section{References}

[1] White, F. (1983) The Vegetation of Africa. Natural Resource Research, UNESCO, 20, 1-356.

[2] Food and Agriculture Organization (1988) Appendix 5, Forest Genetics Resource Priorities 10, Africa. Report of the 6th Session of the FAO Panel of Experts on Forest Gene Resource Held in Rome, Rome, 8-11 December 1985, 65-69.

[3] Maranz, S., Kpikpi, W., Wiesman, Z., De Saint Sauveur, A. and Chapagain, B. (2004) Nutritional Values and Indigenous Preferences for Shea (Vitellaria paradoxa C. F. Gaertn) Fruits in African Agroforestry Parklands. Economic Botany, 58, 588-600.

[4] Irvine, F.R. (1991) Woody Plants of Ghana. Oxford University Press, London.

[5] Adomako, D. (1974) Comparative of Cocoa, Sheanut and Tallow ( Pentedesma Butyraceae Species) Fats. Annual Report, Cocoa Research Institute of Ghana, 178-179.

[6] Adomako, D. (1975) Cocoa Butter and Tallow Fat. Annual Report, Cocoa Research Institute of Ghana, 65.

[7] Hall, J.B., Aebischer, D.P., Tomlinson, H.F., Osei-Amaning, E. and Hindle, H.R. (1996) Vitellaria paradoxa: A Monograph. School of Agriculture and Forest Sciences Publication No. 8, University of Wales, Bangor, 105 p.

[8] Yeboah, J., Lowor, S.T. and Amoah, F.M. (2009) The Rooting Performance of Shea (Vitellaria paradoxa C. F. Gaertn) Cuttings Leached in Water and Application of Rooting Hormone in Different Media. Journal of Plant Sciences, 4, 10-14. http://dx.doi.org/10.3923/jps.2009.10.14

[9] Yeboah, J., Lowor, S.T. and Amoah, F.M. (2009) The Rooting Performance of SHEA (Vitellaria paradoxa C. F. Gaertner) Cuttings as Influence by Wood Type Sucrose and Rooting Hormone. Scientific Research and Essay, 4, 521-525.

[10] Yeboah, J., Lowor, S.T., Amoah, F.M. and Owusu-Ansah, F. (2010) Propagation Structures and Some Factors That Affect the Rooting Performance of Shea (Vitellaria paradoxa C. F. Gaertn) Cuttings. Agriculture and Biology Journal of North America, 2, 258-269. http://dx.doi.org/10.5251/abjna.2011.2.2.258.269

[11] Yeboah, J., Lowor, S.T., Boateng, P.Y. and Amoah, F.M. (2010) Some Physiological and Environmental Factors That Affect the Vegetative Propagation of the Shea (Vitellaria paradoxa C. F. Gaertn) Tree. International Journal of Tropical Agriculture and Food Systems, 3, 170-177.

[12] Akakpo, B., Amissah, N., Yeboah, J. and Blay, E. (2013) Effect of Indole-3-Butyric Acid and Media Type on Adventitious Root Formation in Shea Tree (Vitellaria paradoxa C. F. Gaertn) Stem Cuttings. American Journal of Plant Sciences, 5, 313-318. http://dx.doi.org/10.4236/ajps.2014.53043

[13] Sanou, H., Kambou, S., Teklehaimanot, Z., Dembele, M., Yossi, H., Sina, S., Djingdia, L. and Bouvet, J.M. (2004) Vegetative Propagation of Vitellaria paradoxa by Grafting. Agroforestry Systems, 60, 93-99. http://dx.doi.org/10.1023/B:AGFO.0000009408.03728.46

[14] Opoku-Ameyaw, K. (1996) Sheanut Experiments. Report of Cocoa Research Institute of Ghana, Bole Substation, 225-228.

[15] Yeboah, J., Banful, B.K.B., Boateng, P.Y., Amoah, F.M., Maalekuu, B.K. and Lowor, S,T. (2014) Rooting Response of Air-Layered Sheanut (Vitellaria paradoxa) Trees to Media and Hormonal Application under Two Different Climatic Conditions. American Journal of Plant Sciences, 5, 1212-1219. http://dx.doi.org/10.4236/ajps.2014.59134

[16] Hartmann, H.T., Kester, D.E., Davies, F.T. and Geneve, R.L. (2002) Plant Propagation, Principles and Practices. 7th Edition, Prentice Hall, Englewood Cliffs, 275-551.

[17] Kozlowski, T.T. and Kramer, P.J. (1979) Physiology of Woody Plants. 2nd Edition, Academic Press, New York.

[18] Noggle, G.R. and Fritz, G.J. (1983) Introductory Plant Physiology. Prentice-Hall Inc., Englewood Cliffs, 245.

[19] Malik, C.P. and Srivastava, A.K. (2002) Textbook of Plant Physiology. Kalyani Publishers, New Delhi.

[20] Haskell, D.E., Flasphler, D.J., Webster, C.R. and Meyer, M.W. (2010) Variation of Soil Temperature, Moisture, and Plant Growth with the Addition of Downed Woody Material and Lakeshore Restoration Sites. Restoration Ecology, 20, 113-121.

[21] Jackson, G. (1968) Notes on West African Vegetation. 3. The Seedling Morphology of Butyrospermum paradoxum (Gaertn. F.) Hepper. Journal of West African Science Association, 13, 215-222.

[22] Hutcheon, V.W., Smith, R.W. and Asomaning, E.J.A. (1973) Effect of Irrigation on the Yield and Physiological Behaviour of Matured Amelonado cocoa in Ghana. Tropical Agriculture, 50, 261-272. 
Scientific Research Publishing (SCIRP) is one of the largest Open Access journal publishers. It is currently publishing more than 200 open access, online, peer-reviewed journals covering a wide range of academic disciplines. SCIRP serves the worldwide academic communities and contributes to the progress and application of science with its publication.

Other selected journals from SCIRP are listed as below. Submit your manuscript to us via either submit@scirp.org or Online Submission Portal.
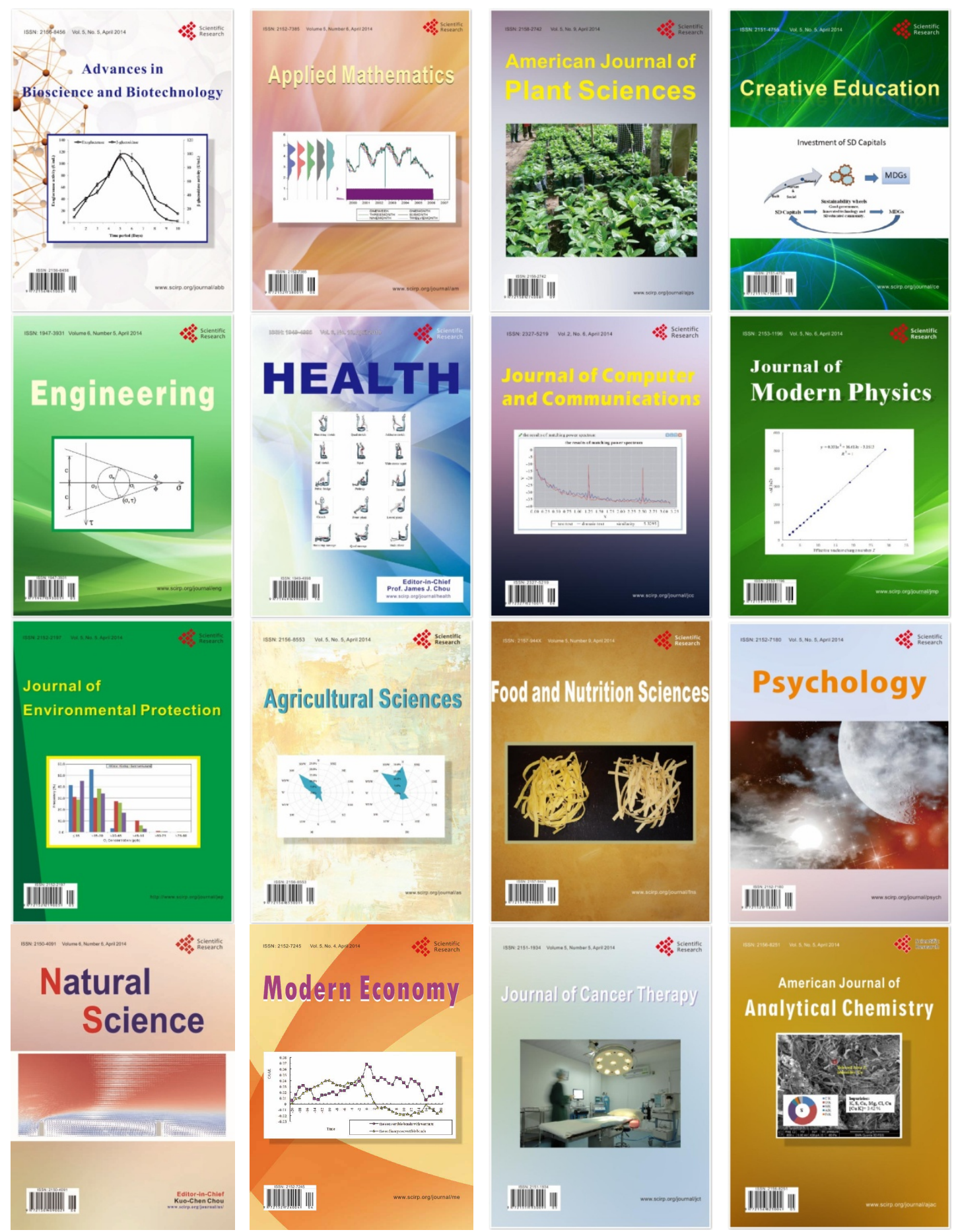